\title{
Biochemical Response of Rice Plant to Biotic and Abiotic Stress under Silica Ions and Nanoparticles Application
}

\author{
H. S. Hegazy, N. SH. Hassan, M. E. F. Abdel-Haliem and D. \\ M. Naguib* \\ Botany Department, Faculty of Science, Zagazig University, \\ Zagazig, Eygpt.
}

\begin{abstract}
CALINITY and wilt disease are of the most popular stress conditions that face crops specially rice, our study aims to evaluate biochemical response of rice plants to wilt disease and salinity stress under silica ions and nanoparticles application. Rice plants grew under Fusarium infection (wilt disease) stress and irrigated with five different concentrations of $\mathrm{NaCl}$ in peat moss incorporated with sodium silicate solution and peat moss similarly supplemented with nanosilica solution, the samples were collected for biochemical analysis in three stages (3, 6 and 9 days from treatment). The pigments, plasma membrane permeability, $\mathrm{H}_{2} \mathrm{O}_{2}$, lipid peroxidation, antioxidant enzymes and proline content were determined. The results showed that the silica ions caused improvement of the biochemical status of rice plants under the applied biotic and abiotic stress, while nano silica caused suppression of these criteria under the same biotic and abiotic stress condition.
\end{abstract}

Keywords: Rice, Silicon, Nanosilica, Fusarium, Salinity.

Silicon ( $\mathrm{Si}$ ) exists in all plants grown in soil and its content in plant tissue ranges from 0.1 to $10 \%$ of dry matter. $\mathrm{Si}$ is considered as a nutrient of agronomic essentiality where its absence causes imbalances of other nutrients resulting in poor growth, if not death of the plant (Savant et al., 1997). There is substantial evidence that when several high $\mathrm{Si}$ accumulator plants are fertilized with $\mathrm{Si}$, they benefit from reduced severity of disease, with associated yield increases over infected plants that weren't fertilized with Si (Datnoff et al., 2001). Two mechanisms for Si-enhanced resistance to diseases have been proposed. One is that $\mathrm{Si}$ acts as a physical barrier, where $\mathrm{Si}$ is deposited beneath the cuticle such that the Si layer mechanically impedes penetration by fungi, thereby disrupting the infection process. The other mechanism proposed is that soluble $\mathrm{Si}$ acts as a modulator of host resistance to pathogens (Ma et al., 2006). Silicon has been shown to be effective in mitigating salinity in recent investigations. The mitigative effect of $\mathrm{Si}$ on salinity has been examined in barley (Liang et al., 2005), cucumber (Zhu et al., 2004), white clover (Guo et al., 2013), soybean (Lee et al., 2010) and tomato (Haghighi and Pessarakli, 2013).The key mechanisms of

*Corresponding author: e-mail: dmna2610science@yahoo.com 
Si-mediated alleviation of abiotic stresses in higher plants include: (1) stimulation of antioxidant systems in plants, (2) complexation or co-precipitation of toxic metal ions with $\mathrm{Si}$, (3) immobilization of toxic metal ions in growth media, (4) improvement uptake processes, and (5) compartmentation of metal ions within plants (Liang et al., 2007).

Toxicity of nanoparticles may be attributed to two different actions: (1) a chemical toxicity based on the chemical composition and (2) stress or stimuli caused by the surface, size and/or shape of the particles. It has been confirmed that solubility of oxide nanoparticles greatly affected the cell culture response (Brunner et al., 2006). Silica $\left(\mathrm{SiO}_{2}\right)$ NPs have found extensive applied in chemical mechanical polishing, drugs, cosmetics, printer toners, varnishes, and food. In recent years, the use of $\mathrm{SiO}_{2} \mathrm{NPs}$ has been extended to biomedical and biotechnological fields (Lin et al., 2006). The toxicity of the $\mathrm{SiO}_{2} \mathrm{NPs}$ depends on: (i) particle size, i.e., a small particle size implies an inhibition of growth and (ii) the effective concentration, i.e., effective concentration increases toxicity decreases (Fujiwara et al., 2008).

Plants employ diverse mechanisms to contend with the adverse environmental conditions, many of which are localized to the plasma membrane (PM). The PM not only functions as a protection barrier or interface involved in the maintenance of ionic and metabolite gradients, but it is directly involved in sensing the diversity of external signals and the transduction of these signals to other sites on the membrane, inside the cell, and distal portions of the plant to provide for direct and rapid responses to changing environmental conditions, and in activating mechanisms that help maintain the cellular homeostasis that is disrupted by the imposition of multiple stress conditions (Barkla and Pantoja, 2011). Alterations in PM permeability under stress have been ascribed to changes in membrane lipids or changes in the membrane transport proteins which affect protein-lipid interaction which finally can alter PM permeability (Wassall and Stillwell, 2009).

Reacive oxygen species (ROS) are produced continuously as byproducts of various metabolic pathways that are localized in different cellular compartments such as chloroplast, mitochondria and peroxisomes (Navrot et al., 2007). ROS are produced in plants and normally exist in the plant cell when the amount of ROS accumulation is maintained at normal levels by a series of antioxidative enzymes and molecules to maintain the redox equilibrium. When plants exposed to various stresses in which plant survival is guaranteed by a proper induction of antioxidant defenses to control the low levels of ROS and maintain redox equilibrium in the plant cell. Oxidative stress occurs when this redox equilibrium is disturbed by excess levels of ROS or depletion of antioxidative defense systems or both, and finally this leads to cell collapse and death (necrosis) in plants (Karuppanapandian et al., 2011).

\section{Material and Methods}

\section{Preparation of silica ions and nanosilica}

Preparation of sodium silicate ions and nano silica from rice straw was carried out by a modified procedure of Adam and Fua (2008) as following: A $30.0 \mathrm{~g}$

Egypt. J. Bot., 55, No. 1 (2015) 
sample of dried rice straw was weighed and transferred into a plastic container. $600 \mathrm{~mL}$ of $1.0 \mathrm{M} \mathrm{HNO}_{3}$ was added into the container and stirred for $24 \mathrm{hr}$ in order to remove unwanted metal. The acid treated rice straw was filtered and washed with distilled water until it reached a constant $\mathrm{pH}$ (4.5-5.0) and dried in oven at $383 \mathrm{~K}$ overnight, The cleaned rice straw was stirred in $500 \mathrm{~mL}$ of $1.0 \mathrm{M}$ $\mathrm{NaOH}$ for $24 \mathrm{hr}$. The mixture was suction filtered to obtain a dark brown filtrate (sodium silicate) which was kept in a covered plastic container for use, The silicon concentration in the prepared solution was determined by atomic absorption spectrophotometer.

The prepared sodium silicate was titrated slowly with $3.0 \mathrm{M} \mathrm{HNO}_{3}$ until it reached $\mathrm{pH}$ 9.0. The yellowish gel obtained was aged in a covered container for 2 days. The gel was recovered by centrifuge at 4,000 rpm and followed by washing with copious amount of distilled water. It was dried in an oven at $383 \mathrm{~K}$ for $24 \mathrm{hr}$. It was allowed to cool. Finally, the product was ground into fine powder and labelled as Nano Silica and characterized by photographing under transmission electron microscope.

\section{Culturing of plant pathogenic fungus}

Fusarium oxysporum was friendly obtained from faculty of Agricultural, Zagazig University, Egypt, and subcultured on Dox agar media for activation then spore suspension is prepared and used as fungal inoculum used for plants infection.

\section{Pot Experiment}

Seeds of rice (Skha 01) were obtained from the Agricultural Research Center, Giza, Egypt.

1- Pot experiments for rice plants were carried out in the green house of the Botany Department, Faculty of Science, Zagazig University. About $2 \mathrm{~kg}$ of soil was taken in plastic pot of $20 \mathrm{~cm}$ diameter.

2- The pots were divided in to 6 groups as following: The first group: The peat moss soil remains as it is without addition.The second group: The peat moss soil supplied with $50 \mathrm{ml}$ of prepared sodium silicate solution $(150 \mathrm{mg} / \mathrm{ml})$ only. The third group: The peat moss soil was supplied with $50 \mathrm{ml}$ of prepares nanosilica solution only (150 g of the prepared nano silica powder was dissolved in liter of dist. Water $(150 \mathrm{mg} / \mathrm{ml}))$. The fourth group: The peat moss soil was inoculated with $20 \mathrm{ml}$ of prepared fungal inoculum only. The fifth group: The peat moss soil was supplied with $50 \mathrm{ml}$ of prepared sodium silicate solution and inoculated with $20 \mathrm{ml}$ of prepared fungal inoculum. The sixth group: The peat moss soil was supplied with $50 \mathrm{ml}$ of prepares nanosilica solution and inoculated with $20 \mathrm{ml}$ of prepared fungal inoculums. 
3- The pots were arranged on green house benches in and kept under natural photoperiod of 12 to $13 \mathrm{hr}$ and temperature of $28 \pm 4^{\circ} \mathrm{C}$.

5- After 20 days from planting each group was divided in to five sub groups according to salt irrigation as following: (No salt irrigation, Irrigated with $100,200,400$ and $800 \mathrm{mM} \mathrm{NaCl}$ solution).

6- The samples were collected at 3,6 and 9 days after salt irrigation treatment.

Determination of plasma membrane permeability (Electrolyte leakage)

The plasma membrane permeability was determined as the electrolyte leakage percent according to Pooviah (1973).

Estimation of photosynthetic pigments

Chlorophyll a, Chlorophyll $\mathrm{b}$ and Carotenoids were determined in the leaves of the investigated plant. The spectrophotometric method recommended by Metzner et al. (1965) was used.

Determination of Hydrogen peroxide $\left(\mathrm{H}_{2} \mathrm{O}_{2}\right)$ content

$\mathrm{H}_{2} \mathrm{O}_{2}$ content was determined according to the method of Alexievia et al. (2001).

Determination of MDA content (Lipid peroxidation)

MDA determination was followed the method described by Li (2000).

Estimation the activities of antioxidant enzymes

A known fresh weight of plant leaves $(0.5 \mathrm{~g})$ was homogenized in $0.05 \mathrm{M}$ cold phosphate buffer ( $\mathrm{pH}$ 6.5) containing $1 \mathrm{mM}$ EDTA, $\mathrm{Na}_{2}$ and centrifuged at $10.000 \mathrm{rpm}$ for $10 \mathrm{~min}$. The supernatant was completed to a total known volume and used as enzyme source (SOD, CAT, PPO and soluble POX) (Ma et al., 2012). The residue was thoroughly washed with distilled water and centrifuged several times. The wall fraction was then kept with $10 \mathrm{ml}$ of $1 \mathrm{M} \mathrm{NaCl}$ for $1 \mathrm{hr}$ to release cell wall bound POX. After centrifugation at $10000 \mathrm{~g}$ for $10 \mathrm{~min}$, the supernatant was used as the source of wall bound POX (saroop et al., 2002).

A- Assay of super oxide dismutase (SOD)

SOD activity was measured by the nitro blue tetrazolium (NBT) reduction method (Beyer and Fridovich, 1987). SOD activities were calculated as a following equation: SOD activity $(\%)=(1-A / B) \times 100(A$ : absorbance of sample; $B$ : absorbance of blank).

$B$ - Assay of catalase activity (CAT)

Accordig to Kar and Mishra (1967). Catalase activity was expressed as $\mu \mathrm{mol}$ $\mathrm{H}_{2} \mathrm{O}_{2}$ destroyed/g f wt /min.

Egypt. J. Bot., 55, No. 1 (2015) 
C- Assay of polyphenol oxidase activity (PPO)

Accordig to (Beyer and Fridovich, 1987). Enzyme activity was expressed as the change in the optical density/g f wt /min.

D- Assay of soluble and cell wall bound peroxidase activity (POX)

Accordig to (Upadhyaya et al., 1985). Enzyme activity was expressed as the change in the optical density/g f wt/min.

\section{Estimation of proline content}

Proline content was determined according to the method of Bates et al. (1973).

\section{Statiscal analysis}

The results were expressed as the mean of three replicates \pm standard error and the means were compared for significance by paired $\mathrm{T}$ test using the spss (version 14) at $\mathrm{p}<0.01$.

\section{Results and Discussion}

Nano silica characterization

The image of silica nanoparticles Fig. 7 is shown that, the shape of precipitated silica nanoparticles is sphere with an average size of about $55-75 \mathrm{~nm}$. Transmission electron microscope (TEM) image shows that narrow size distribution of silica particles are obtained.

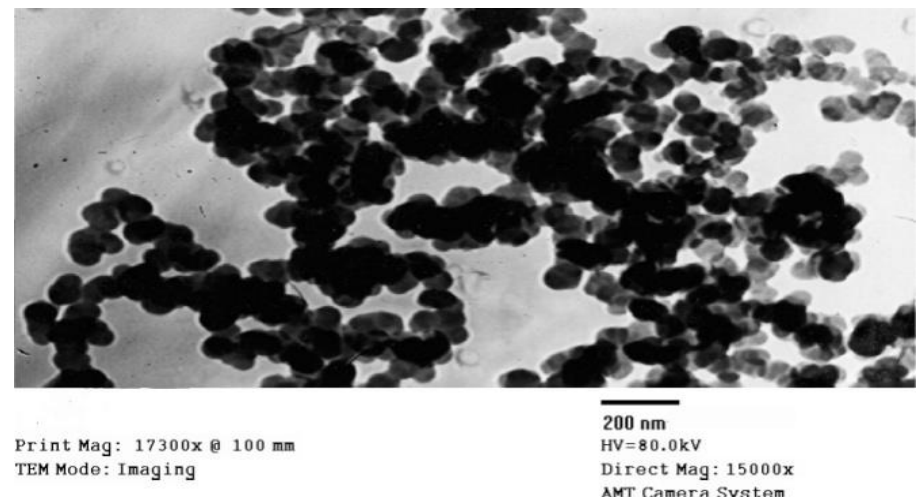

Fig. 1. TEM of silica nanoparticles prepared from rice straw.

Plasma membrane permeability (Electrolyte leakage percent)

The results in Figs. 2-7 show that the silica ions or nanosilica application led to non significant decrease in plasma membrane permeability (PMP). The salt irrigation and/or Fusarium infection cause significant increase in PMP in case of non-treated plants and nanosilica treated plants but in the nanosilica treated plants Egypt. J. Bot., 55, No. 1 (2015) 
the increase is in lower rate compared with the non treated plants, while in the silica ions treated plants the PMP increase non significantly. The decrease in the PMP explained as lipid composition altered due to stress (Zamani et al., 2010). The mechanism by which lipid peroxidation increases PM permeability might be that lipid peroxidation products are responsible for ordering phospholipids into gel phase which destabilizes the membrane structure (Russell, 1989).The reduced changes in PM lipids induced by stress are expected to promote maintenance of membrane integrity and cellular homeostasis in silicon treated samples. Such membrane adaptation might be, however, lacking in other samples (untreated samples and nano silica treated samples (Mansour, 2013). Also stress-induced changes in the membrane transport proteins can also affect protein-lipid interaction which finally can alter PMP. It is possible that membrane transport proteins first undergo conformational changes, which in turn, disturb specific molecular interactions between lipids and proteins and eventually affects membrane permeability (Mansour, 1997). Additionally, changes in the configuration of membrane proteins could also lead to different spacing of the phospholipids, because of the polar interactions between both types of molecules. This can further affect PM permeability. Moreover, stress-induced changes in lipid microenvironment around transport proteins affect their kinetic properties and the efficiency of the transport systems (reflected in increased PMP) (Amtmann and Beilby, 2010). It is reasonable, therefore, to conclude that membrane protein alterations under stress might be enhanced in untreated samples and nano silica treated samples, but not so much in silica ions treated ones (Jacobs et al., 2011).

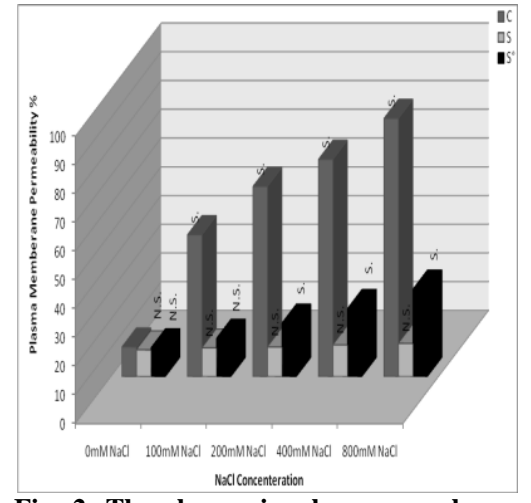

Fig. 2. The change in plasma membrane permeability (ion leakage) percent in Rice seedlings after 3 days from salt irrigation either in non treated seedlings (C) or seedlings treated with silica ions (S) or seedlings treated with nano silica $\left(\mathbf{S}^{\mathbf{o}}\right)$.

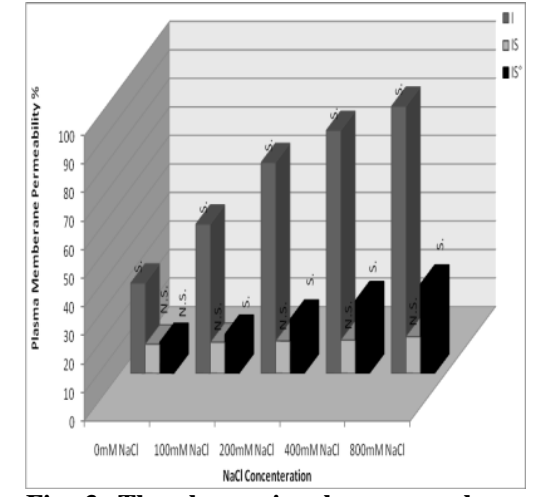

Fig. 3. The change in plasma membrane permeability (ion leakage) percent in Rice seedling after 3 days from salt irrigation and Fusarium infection either in in non treated seedlings (I) or seedlings treated with silica ions (IS) or seedlings treated with nano silica $\left(\mathbf{I S}^{\mathbf{o}}\right)$. 


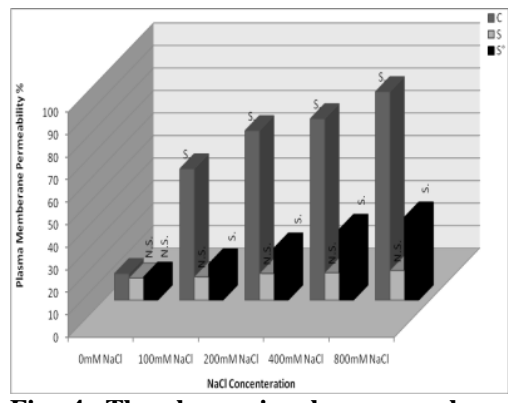

Fig. 4. The change in plasma membrane permeability (ion leakage) percent in Rice seedlings after 6 days from salt irrigation

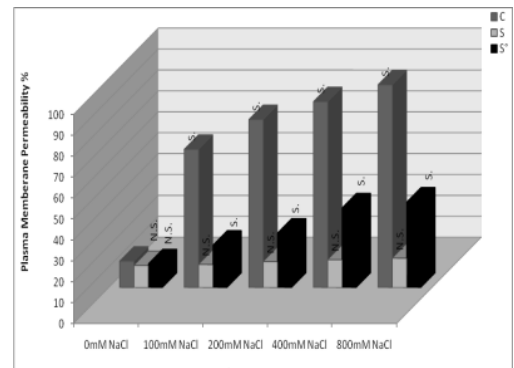

Fig. 6. The change in plasma membrane permeability (ion leakage) percent in Rice seedlings after 9 days from salt irrigation .

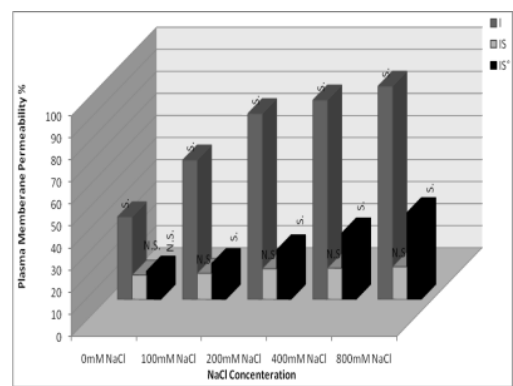

Fig. 5. The change in plasma membrane permeability (ion leakage) percent in Rice seedling after 6 days from salt irrigation and Fusarium infection .

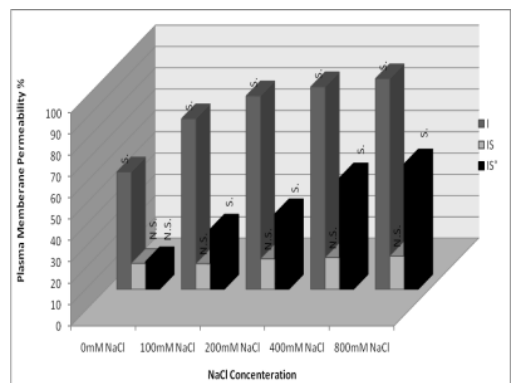

Fig. 7. The change in plasma membrane permeability (ion leakage) percent in Rice seedling after 9 days from salt irrigation and Fusarium infection.

\section{Pigments content}

The results in Figs. 8- 25 show that application of silica ions resulted in significant increase in both chlorophylls and non significant in cartenoids while the nanosilica application resulted in non significant decrease in all analyzed pigments (chlorophyll a, chlorophyll $b$ and carotenoid respectively). Salt irrigation or Fusarium infection resulted in continuous significant decrease in the pigments incase of the normal conditions or in the nanosilica application, while partially non significant decrease was shown in case of silica ions application. The content increased with time in contrast with the other two cases. The reduction in leaf chlorophyll content under stress has been attributed to destruction of chlorophyll pigments and instability of the pigment protein complex also attributed to the interference with the synthesis of proteins (The structural component of chlorophyll) rather than the breakdown of chlorophyll (Jaleel et al., 2007). Reduction in chlorophyll concentrations is probably due to the inhibitory effect of the accumulated toxic ions (Ali et al., 2012). In case of Si 
treated plants $\mathrm{Si}$ helps in the reduction of toxic ions, increase protein stability (Liang et al., 2007). Stress induces degradation of $\beta$-carotene, which causes a decrease in the content of carotenoids that are integrated constituents of thylakoid membranes and act in absorption and light transfer to chlorophyll as well as protection of chlorophyll from photooxidation (Maria Antonia Machado Barbosa et al., 2014). Si treated plants show none significant decrease in the cartenoids under stress as Si help in stabilizing the membranes (Mansour, 2013) and protection of the cartenoids from degradation (Liang et al., 2007).

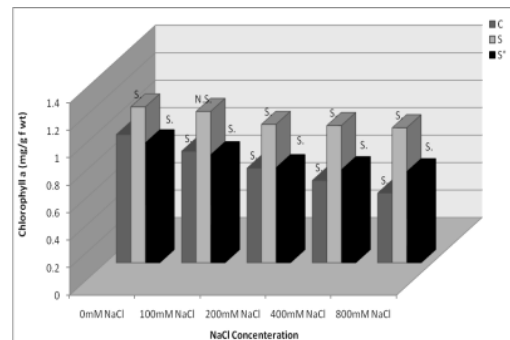

Fig. 8. The change in chlorophyll a content in Rice seedlings after 3 days from salt irrigation either in non treated seedlings (C) or seedlings treated with silica ions (S) or seedlings treated with nano silica $\left(S^{\circ}\right)$.

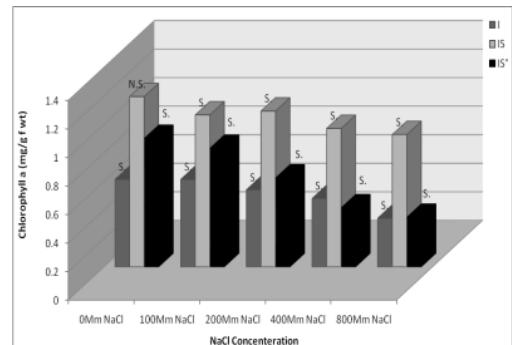

Fig. 10. The change in chlorophyll a content in Rice seedlings after 6 days from salt irrigation .

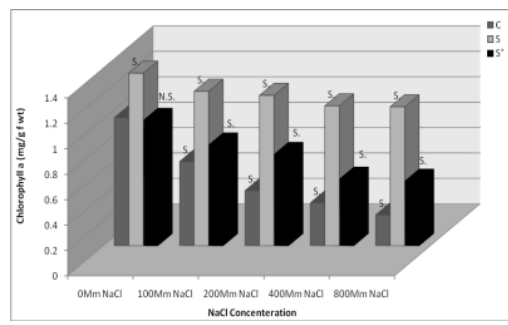

Fig. 12. The change in chlorophyll a content in Rice seedlings after 9 days from salt irrigation .

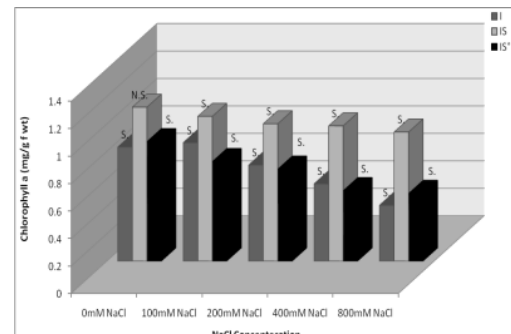

Fig. 9. The change in chlorophyll a content in Rice seedling after $\mathbf{3}$ days from salt irrigation and Fusarium infection either in in non treated seedlings (I) or seedlings treated with silica ions (IS) or seedlings treated with nano silica $\left(\right.$ IS $\left.^{\circ}\right)$.

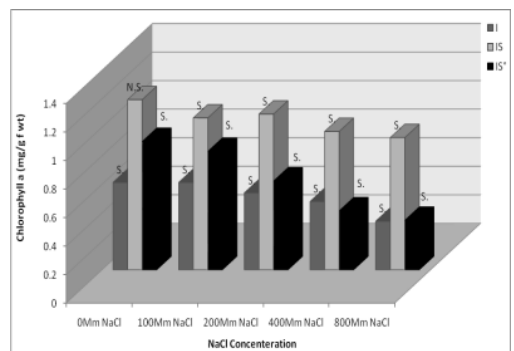

Fig. 11. The change in chlorophyll a conten in Rice seedling after 6 days from salt irrigation and Fusarium infection .

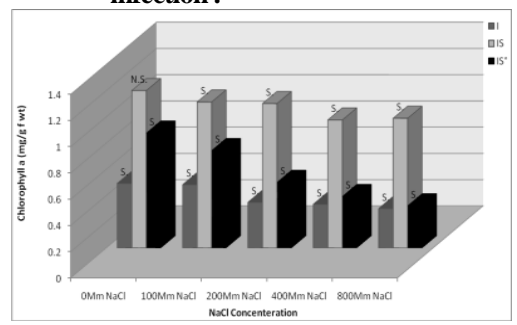

Fig. 13. The change in chlorophyll a content in Rice seedling after 9 days from salt irrigation and Fusarium infection. 


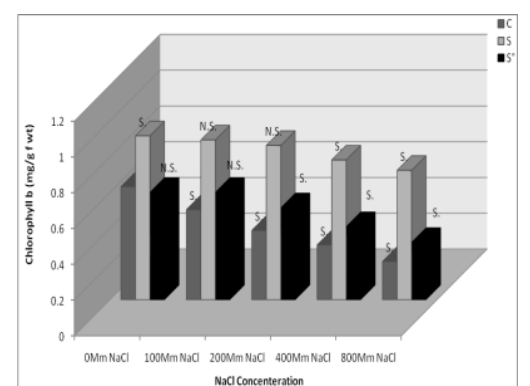

Fig. 14. The change in chlorophyll b content in Rice seedlings after 3 days from salt irrigation either in non treated seedlings (C) or seedlings treated with silica ions (S) or seedlings treated with nano silica $\left(S^{\circ}\right)$.

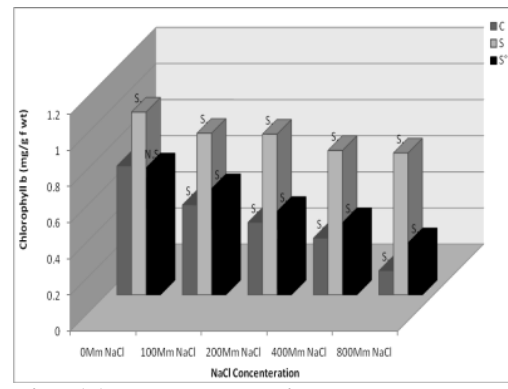

Fig. 16. The change in chlorophyll b content in Rice seedlings after 6 days from salt irrigation .

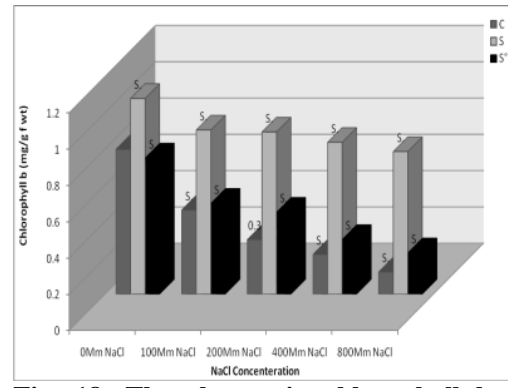

Fig. 18. The change in chlorophyll b content in Rice seedlings after 9 days from salt irrigation .

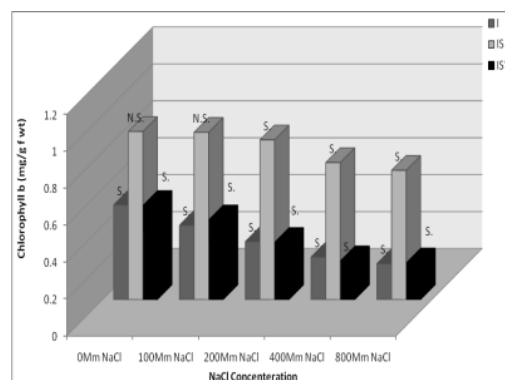

Fig. 15. The change in chlorophyll b content in Rice seedling after 3 days from salt irrigation and Fusarium infection either in in non treated seedlings (I) or seedlings treated with silica ions (IS) or seedlings treated with nano silica $\left(\mathrm{IS}^{\mathbf{o}}\right)$.

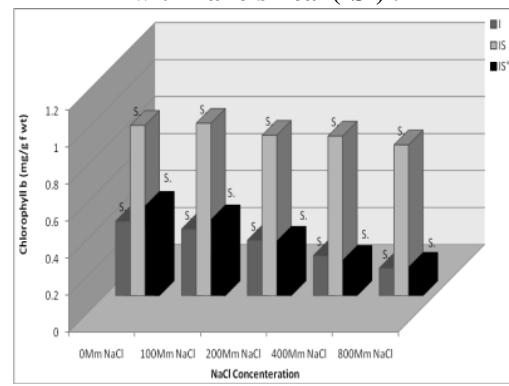

Fig. 17. The change in chlorophyll b content percent in Rice seedling after 6 days from salt irrigation and Fusarium infection .

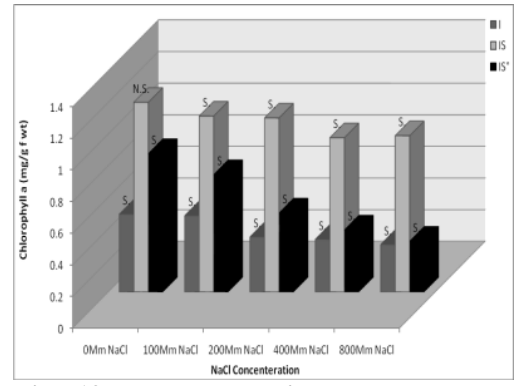

Fig. 19. The change in chlorophyll b content in Rice seedling after 9 days from salt irrigation and Fusarium infection . 


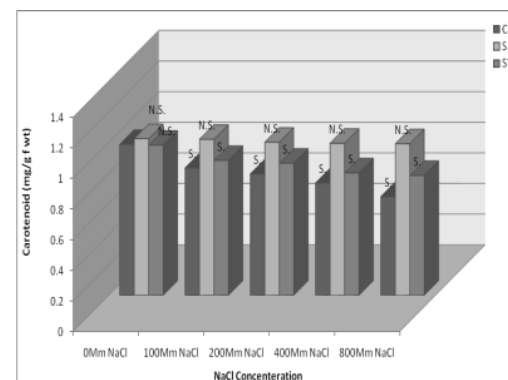

Fig. 20. The change in carotenoid content in Rice seedlings after 3 days from salt irrigation either in non treated seedlings (C) or seedlings treated with silica ions (S) or seedlings treated with nano silica $\left(\mathbf{S}^{\circ}\right)$.

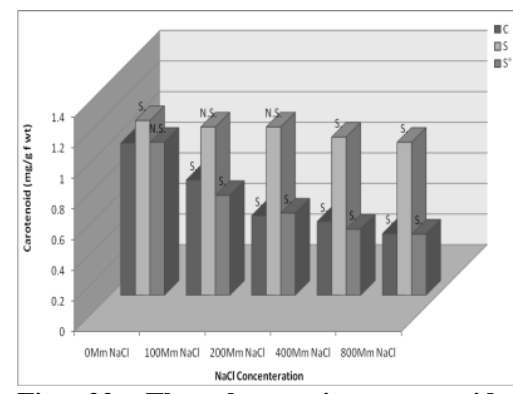

Fig. 22. The change in carotenoid content in Rice seedlings after 6 days from salt irrigation .

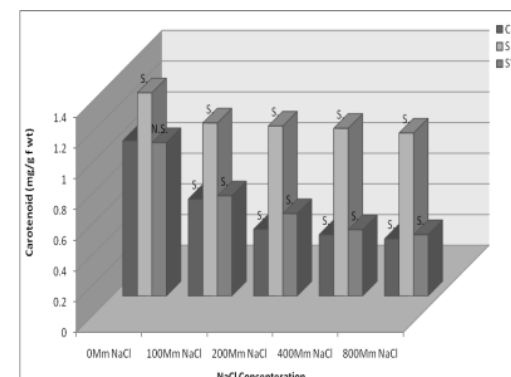

Fig. 24. The change in carotenoid content in Rice seedlings after 9 days from salt irrigation .

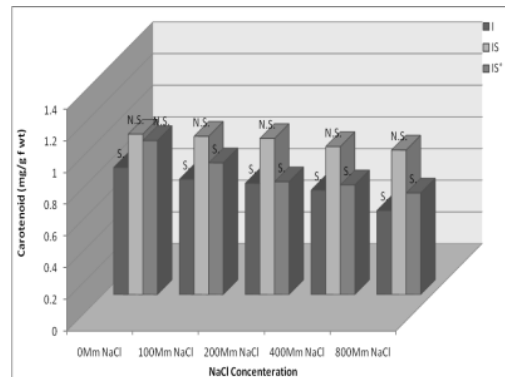

Fig. 21. The change in carotenoid content in Rice seedling after 3 days from salt irrigation and Fusarium infection either in in non treated seedlings (I) or seedlings treated with silica ions (IS) or seedlings treated with nano silica $\left(\right.$ IS $^{\mathbf{o}}$ ) .

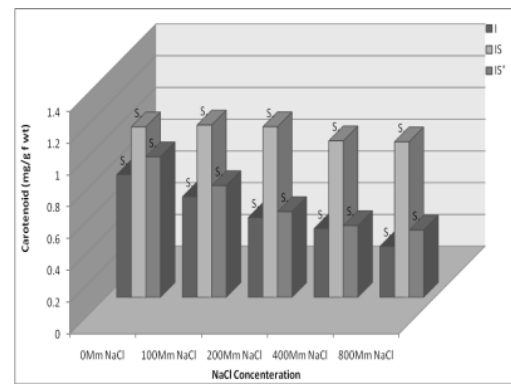

Fig. 23. The change in carotenoid content in Rice seedling after 6 days from salt irrigation and Fusarium infection.

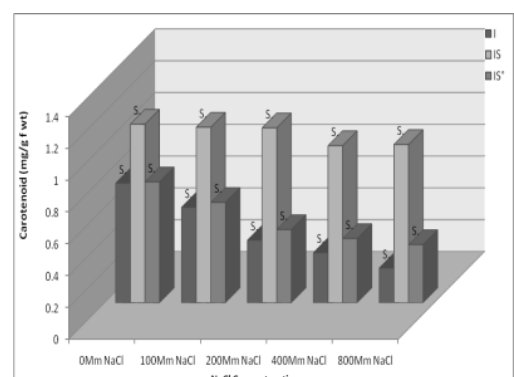

Fig. 25. The change in carotenoid content in Rice seedling after 9 days from salt irrigation and Fusarium infection .

\section{$\mathrm{H}_{2} \mathrm{O}_{2}$ content}

Egypt. J. Bot., 55, No. 1 (2015) 
The results in Figs. 26-31 show that silica ions application non significantly decrease the $\mathrm{H}_{2} \mathrm{O}_{2}$ content while with nanosilica application non significant increase. Salt irrigation and/or infection caused in significant increase in the $\mathrm{H}_{2} \mathrm{O}_{2}$ content in the three cases (normal, nanosilica application and silica ions application). However in case of the silica ions application $\mathrm{H}_{2} \mathrm{O}_{2}$ decrease with time and diminished in the last stage ( 9 days after salt irrigation), in contrast with the two other cases in which $\mathrm{H}_{2} \mathrm{O}_{2}$ increase with time. As a kind of reactive oxygen species (ROS), $\mathrm{H}_{2} \mathrm{O}_{2}$ has been given much attention during the last decades. Ample evidence has proven that $\mathrm{H}_{2} \mathrm{O}_{2}$ plays an important role in plants under various biotic and abiotic stress (Petrov and Van Breusegem, 2012). Stress activates a class of cell membrane NADPH dependent oxidases like respiratory burst oxidase homologues (Rboh), which are regulated by a unique class of Rho-like proteins called ROPs (Rho-related GTPases from plants) (Agrawal et al., 2003). In case of $\mathrm{Si}$ treatment $\mathrm{H}_{2} \mathrm{O}_{2}$ content increased in the first stage in low rate and then decrease with the time as firstly increase in low rate might indicate that it acts as a signal molecule involved in acclimatory signaling triggering tolerance against various abiotic and biotic stress (Mittler et al. 2004). $\mathrm{H}_{2} \mathrm{O}_{2}$ takes part in resistance mechanism, reinforcement of plant cell wall (lignification, cross-linking of cell wall structural proteins), phytoalexin production and resistance enhancement (Dempscy and Klessig 1995). $\mathrm{H}_{2} \mathrm{O}_{2}$ production in plants induces resistance to various stresses and protects plant from being hurt. It has been suggested that $\mathrm{H}_{2} \mathrm{O}_{2}$ is not only a defensive signal molecule but it also functions as a signal molecule during plant growth and development (Bhattacharjee, 2005). $\mathrm{H}_{2} \mathrm{O}_{2}$ content decrease with time, in the present work, might be explained on the basis that $\mathrm{Si}$ activate a vast network of antioxidants which are constantly on the alert for rising $\mathrm{H}_{2} \mathrm{O}_{2}$ concentrations and provides effective scavenging for it (Miller et al., 2010).

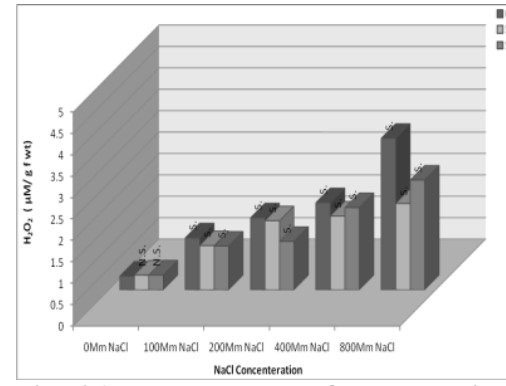

Fig. 26. The change $\mathrm{H}_{2} \mathrm{O}_{2}$ content in Rice seedlings after 3 days from salt irrigation either in non treated seedlings $(C)$ or seedlings treated with silica ions (S) or seedlings treated with nano silica $\left(\mathbf{S}^{\mathbf{o}}\right)$.

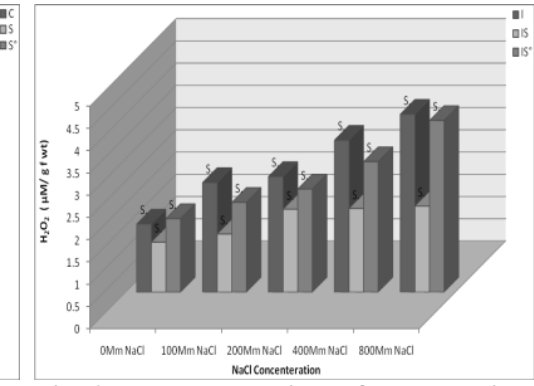

Fig. 27. The change in $\mathrm{H}_{2} \mathrm{O}_{2}$ content in Rice seedling after 3 days from salt irrigation and Fusarium infection either in in non treated seedlings (I) or seedlings treated with silica ions (IS) or seedlings treated with nano silica $\left(\mathrm{IS}^{\mathbf{o}}\right)$. 


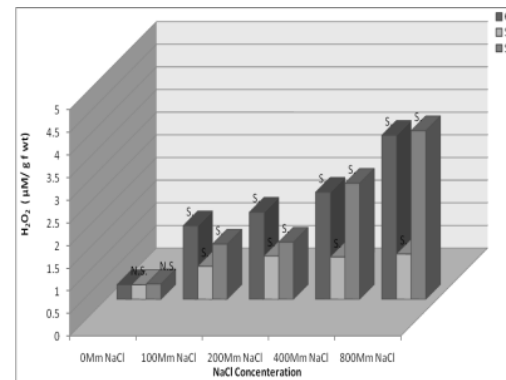

Fig. 28. The change $\mathrm{H}_{2} \mathrm{O}_{2}$ content in Rice seedlings after 6 days from salt irrigation

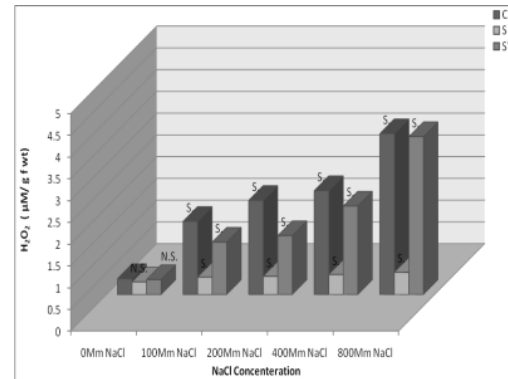

Fig. 30. The change in $\mathrm{H}_{2} \mathrm{O}_{2}$ content in Rice seedlings after 9 days from salt irrigation .

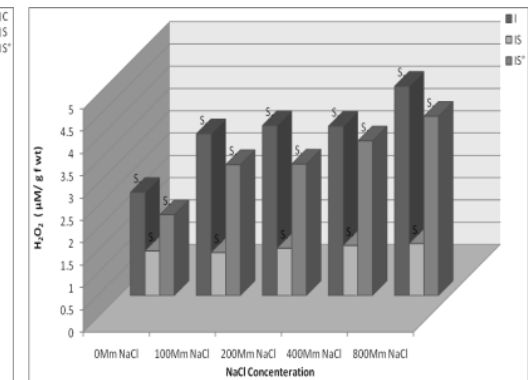

Fig. 29. The $\mathrm{H}_{2} \mathrm{O}_{2}$ content in Rice seedling after 6 days from salt irrigation and Fusarium infection .

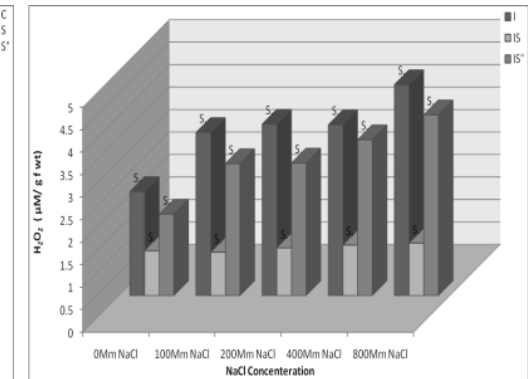

Fig. 31. The change in $\mathrm{H}_{2} \mathrm{O}_{2}$ content in Rice seedling after 9 days from salt irrigation and Fusarium infection.

\section{Malonyldialdehyde (MDA) content}

The results in Figs. 32-37 show that Silica ions application significantly decreased the MDA content in rice and the nano silica application non significantly increased its content. Salt irrigation and/or infection caused in significant increase in the MDA content in normal and nano silica application and non significantly in case of the silica ions application. In case of the silica ions application the content decrease with the time in contrast with the two other cases in which the content increase with time. Currently, lipid peroxidation (LPO) is considered as the main molecular mechanisms involved in the oxidative damage to cell structures and in the toxicity process that lead to cell death (Dianzani and Barrera, 2008). various stresses cause an increase in LPO due to the generation of ROS (Wang and song, 2009). In case of silica treatment Si induce cells to generate ROS scavenging antioxidant system which minimize the ROS generation and so LPO increased at low ratio then decreased with time (Karuppanapandian et al., 2011). This helps in minimizing the toxic effect of LPO to the membrane as LPO caused decrease membrane fluidity; make it easier for phospholipids to exchange between the two halves of the bilayer; increase the leakiness of the membrane to substances that do not normally cross it other than through specific channels and damage membrane proteins, inactivating receptors, enzymes, and ion channels. This help the silica treatment to increase the resistance of cells to stress (Fam and Morrow, 2003).

Egypt. J. Bot., 55, No. 1 (2015) 


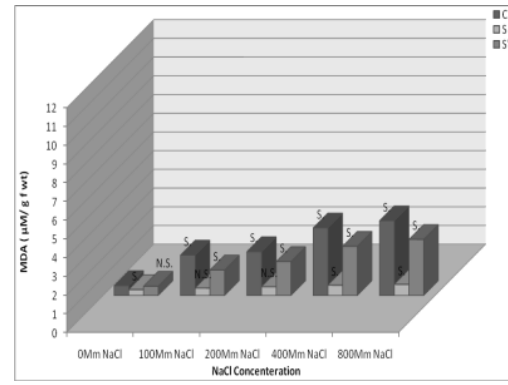

Fig. 32. The change in in MDA content in Rice seedlings after 3 days from salt irrigation either in non treated seedlings (C) or seedlings treated with silica ions (S) or seedlings treated with nano silica $\left(\mathbf{S}^{\circ}\right)$.

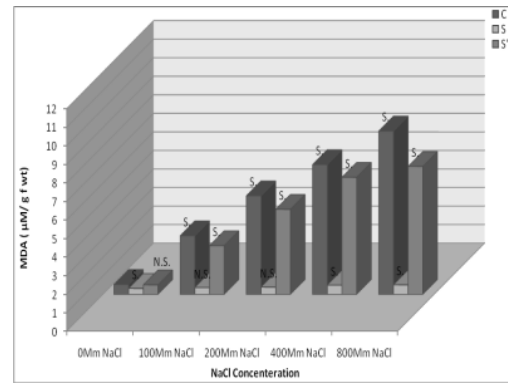

Fig. 34. The change in MDA content in Rice seedlings after 6 days from salt irrigation .

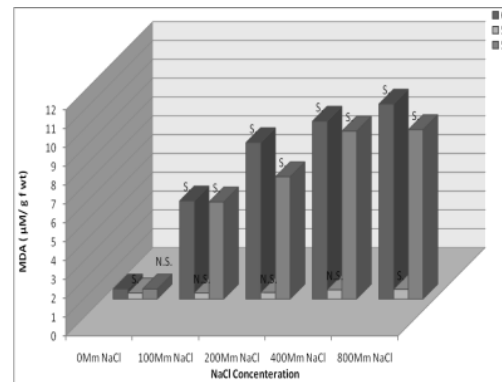

Fig. 36. The change in MDA content in Rice seedlings after 9 days from salt irrigation .

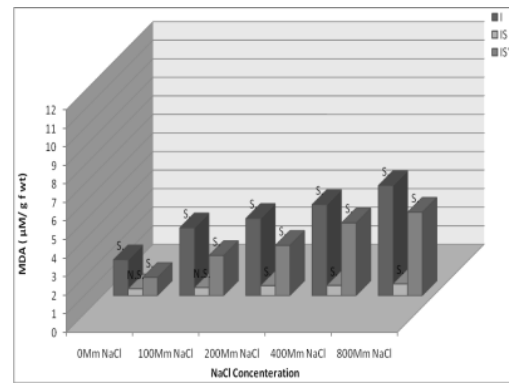

Fig. 33. The change in MDA content in Rice seedling after 3 days from salt irrigation and Fusarium infection either in in non treated seedlings (I) or seedlings treated with silica ions (IS) or seedlings treated with nano silica $\left(\mathbf{I S}^{\circ}\right)$.

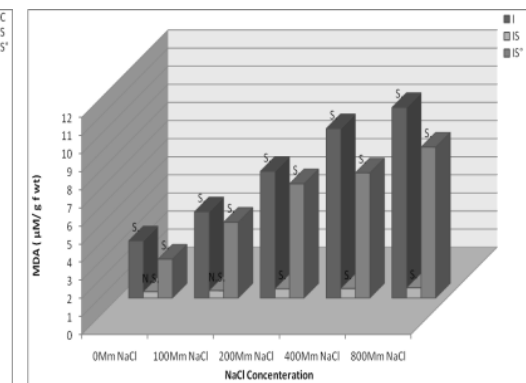

Fig. 35. The change in MDA content in Rice seedling after 6 days from salt irrigation and Fusarium infection

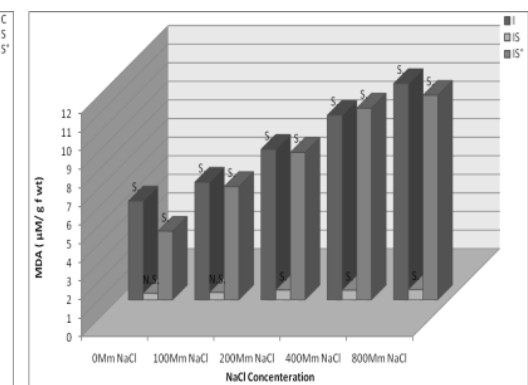

Fig. 37. The change in MDA content in Rice seedling after 9 days from salt irrigation and Fusarium infection .

Egypt. J. Bot., 55, No. 1 (2015) 


\section{Antioxidant enzymes}

Results in Figs. 38-67 show the change in super oxide dismutase (SOD), catalase (CAT), polyphenol oxidase (PPO), soluble and cell wall bound Peroxidase (POX) activity in rice plants as a result of salt irrigation and/ or Fusarium infection either in silica ions application or nano silica application. Thus, in normal conditions no salt irrigation nor Fusarium infection silica ions treatment and nano silica treatment caused non significant increase in the activity, while under salt irrigation and/or Fusarium infection activity in the non treated plants and plants treated with nano silica increased significantly in the first stage while in the other two stages the activity decrease to be almost non significant higher than the control. In plants treated with silica ions the activity increased significantly in the three stages. The increase in antioxidant enzymes activity as aresult of stress might be due to the increase in the ROS content that act as signaling molecules to increase the activity of the antioxidant system including the antioxidant enzymes to prevent the increase in ROS content in toxic manner and save the equilibrium between the ROS and the antioxidant system (Sharma et al., 2012). The activity decrease in case of the non treated samples and the nano silica treated samples with time might be explained as with increasing the stress the proteolytic enzymes become more active which destroy the antioxidant enzymes (Gomathi et al., 2013). Stress also leads to destroying the cell wall and the membrane and cause oxidative damage of membrane proteins which induces destabilization of their configuration so the activity of the cell wall bound peroxidase decrease (Gill and Tuteja, 2010). In case of silica treated samples Si helps in deactivate the proteolytic enzymes and increases protein stability so the activity of the antioxidant enzymes remain active and increase with the stress exposure time with increasing the ROS content (Liang et al., 2007), also silicon help in cell wall lignification which increase the cell wall bound peroxidase (Terzi et al., 2013).

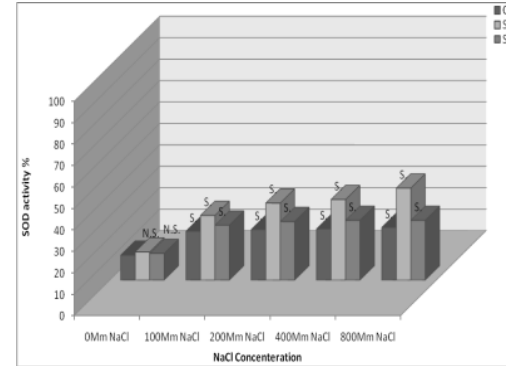

Fig. 38. The change in SOD activity in Rice seedlings after 3 days from salt irrigation either in non treated seedlings (C) or seedlings treated with silica ions (S) or seedlings treated with nano silica $\left(\mathrm{S}^{\circ}\right)$.

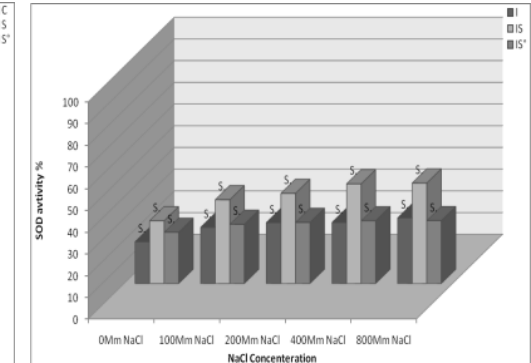

Fig. 39. The change in SOD activity in Rice seedling after 3 days from salt irrigation and Fusarium infection either in in non treated seedlings (I) or seedlings treated with silica ions (IS) or seedlings treated with nano silica (IS ${ }^{\circ}$. 


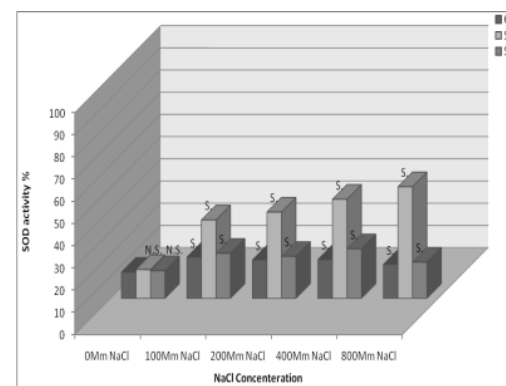

Fig. 40. The change SOD activity in Rice seedlings after 6 days from salt irrigation.

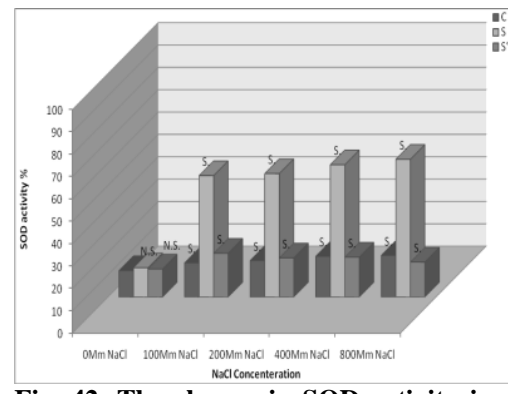

Fig. 42. The change in SOD activity in Rice seedlings after 9 days from salt irrigation .

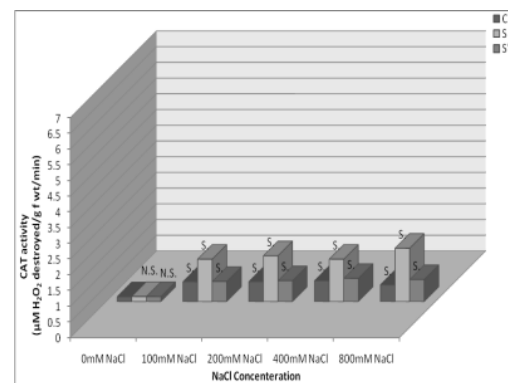

Fig. 44. The change CAT activity in Rice seedlings after 3 days from salt irrigation either in non treated seedlings $(\mathrm{C})$ or seedlings treated with silica ions (S) or seedlings treated with nano silica $\left(\mathbf{S}^{\mathbf{o}}\right)$.

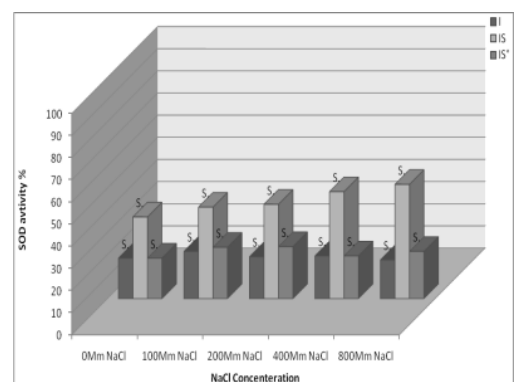

Fig. 41. The change SOD activity in Rice seedling after 6 days from salt irrigation and Fusarium infection .

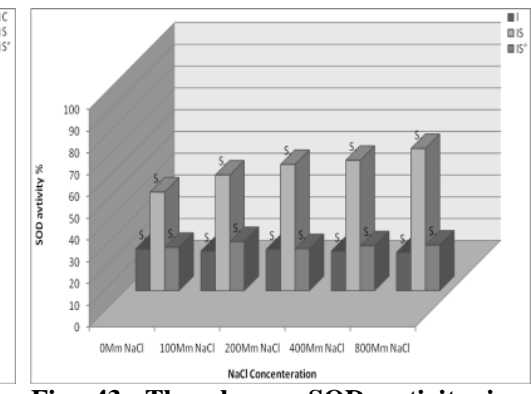

Fig. 43. The change SOD activity in Rice seedling after 9 days from salt irrigation and Fusarium infection .

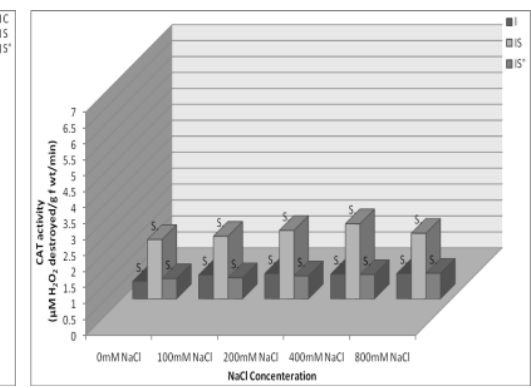

Fig. 45. The change in CAT activity in Rice seedling after 3 days from salt irrigation and Fusarium infection either in in non treated seedlings (I) or seedlings treated with silica ions (IS) or seedlings treated with nano silica $\left(\mathrm{IS}^{\mathbf{o}}\right)$.

Egypt. J. Bot., 55, No. 1 (2015) 


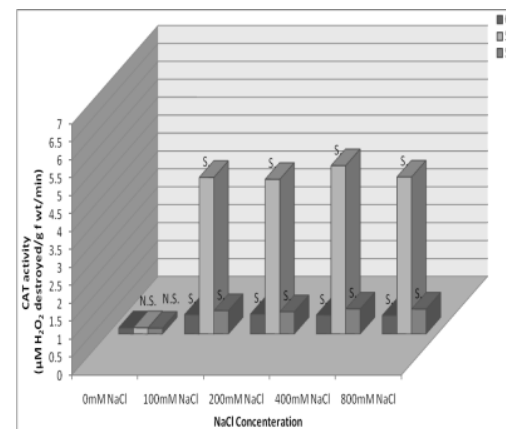

Fig. 46. The change in CAT activity in Rice seedlings after 6 days from salt irrigation

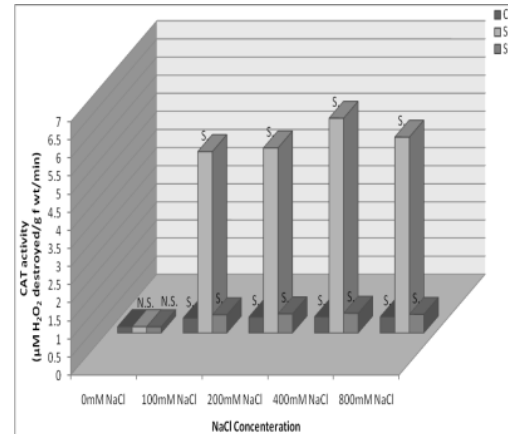

Fig. 48. The change in CAT activity in Rice seedlings after 9 days from salt irrigation .

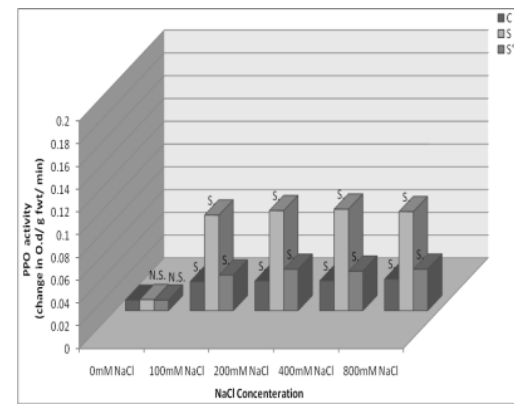

Fig. 50. The change in PPO activity in Rice seedlings after 3 days from salt irrigation either in non treated seedlings (C) or seedlings treated with silica ions (S) or seedlings treated with nano silica $\left(\mathbf{S}^{\mathbf{o}}\right)$

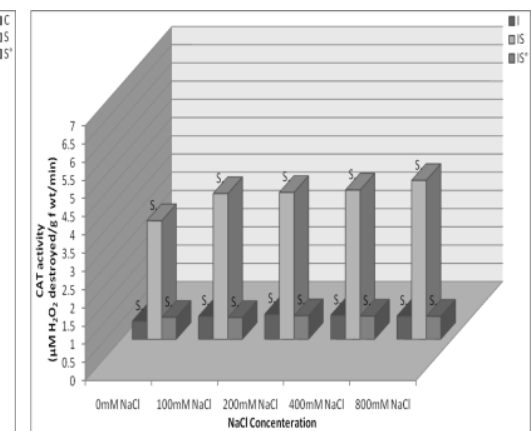

Fig. 47. The change in CAT activity in Rice seedling after 6 days from salt irrigation and Fusarium infection.

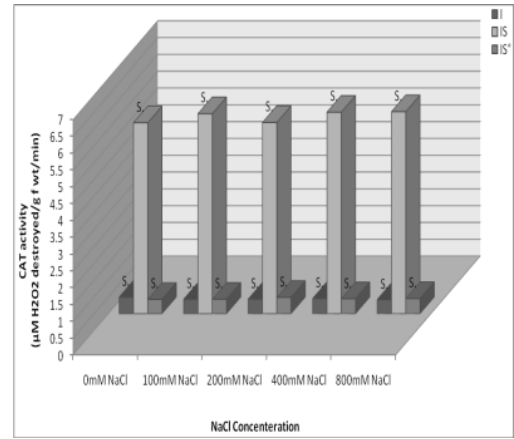

Fig. 49. The change in CAT activity in Rice seedling after 9 days from salt irrigation and Fusarium infection .

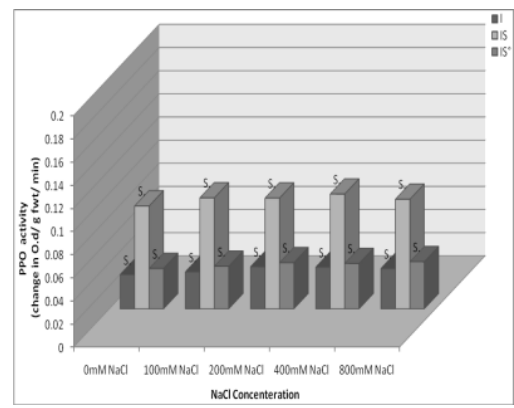

Fig. 51. The change in PPO activity in Rice seedling after 3 days from salt irrigation and Fusarium infection either in in non treated seedlings (I) or seedlings treated with silica ions (IS) or seedlings treated with nano silica $\left(\right.$ IS $\left.^{\circ}\right)$ 


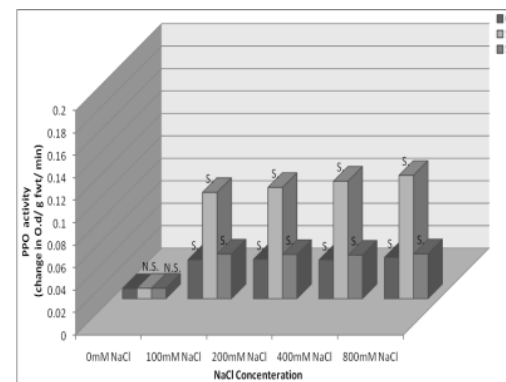

Fig. 52. The change in PPO activity in Rice seedlings after 6 days from salt irrigation .

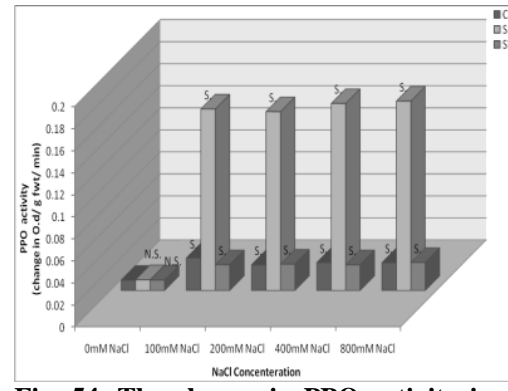

Fig. 54. The change in PPO activity in Rice seedlings after 9 days from salt irrigation .

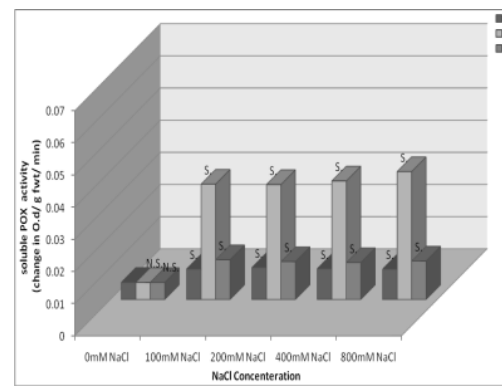

Fig. 56. The change in soluble POX acivity in Rice seedlings after 3 days from salt irrigation either in non treated seedlings (C) or seedlings treated with silica ions (S) or seedlings treated with nano silica $\left(S^{o}\right)$.

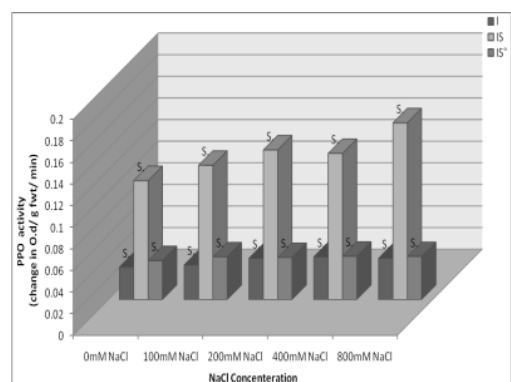

Fig. 53. The change in PPO activity in Rice seedling after 6 days from salt irrigation and Fusarium infection .

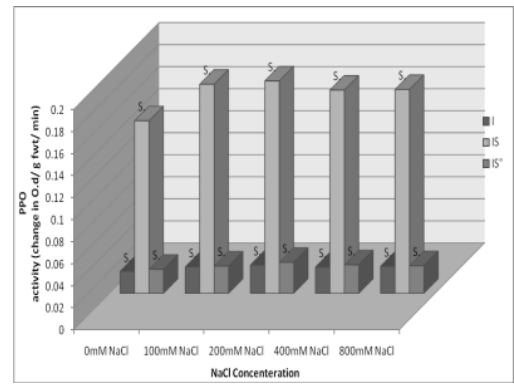

Fig. 55. The change in PPO activity in Rice seedling after 9 days from salt irrigation and Fusarium infection .

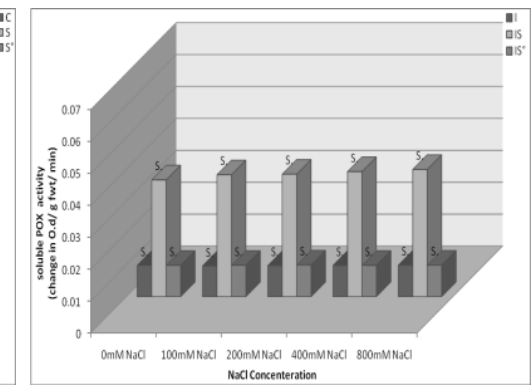

Fig. 57. The change in soluble POX acivity in Rice seedling after 3 days from salt irrigation and Fusarium infection either in in non treated seedlings (I) or seedlings treated with silica ions (IS) or seedlings treated with nano silica $\left(\mathrm{IS}^{\mathbf{o}}\right)$.

Egypt. J. Bot., 55, No. 1 (2015) 


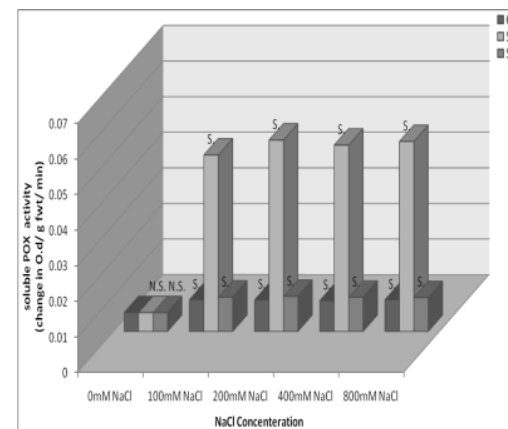

Fig. 58. The change soluble POX acivity in Rice seedlings after 6 days from salt irrigation .

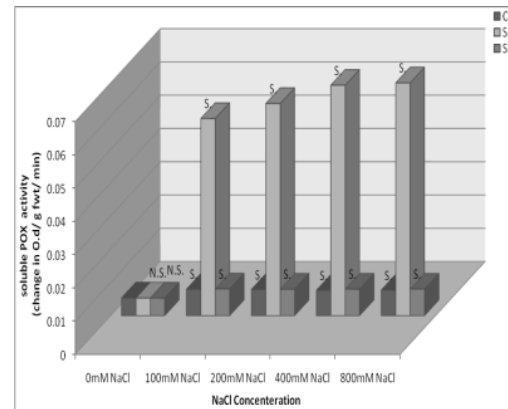

Fig. 60. The change in soluble POX acivity in Rice seedlings after 9 days from salt irrigation .

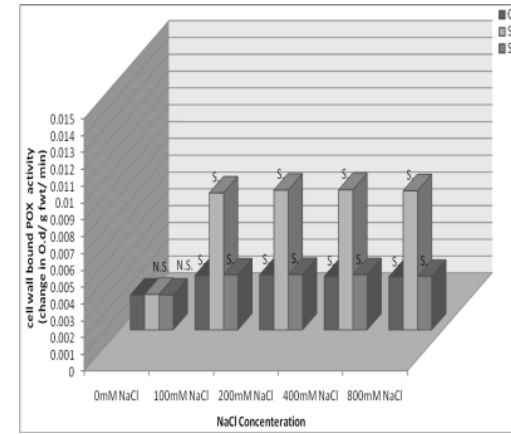

Fig. 62. The change in cell wall bound POX activity in Rice seedlings after 3 days from salt irrigation either in non treated seedlings (C) or seedlings treated with silica ions (S) or seedlings treated with nano silica $\left(\mathbf{S}^{\mathbf{o}}\right)$.

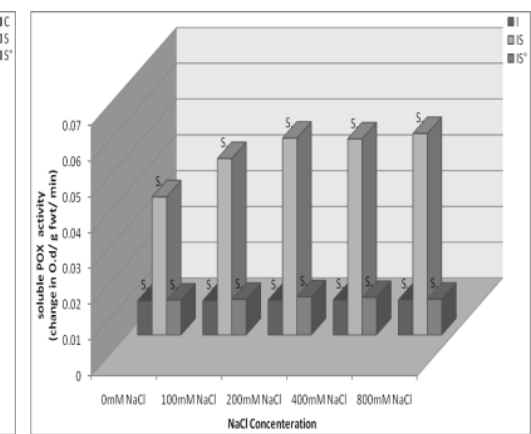

Fig. 59. The change in soluble POX acivity in Rice seedling after 6 days from salt irrigation and Fusarium infection.

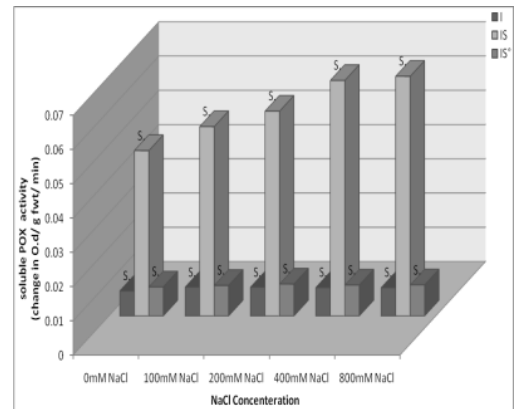

Fig. 61. The change in soluble POX acivity in Rice seedling after 9 days from salt irrigation and Fusarium infection .

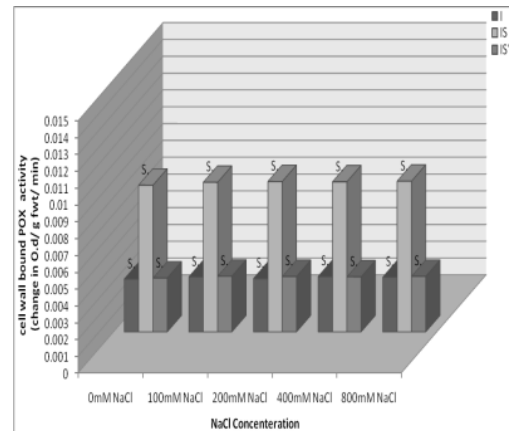

Fig. 63. The change in cell wall bound POX activity in Rice seedling after 3 days from salt irrigation and Fusarium infection either in in non treated seedlings (I) or seedlings treated with silica ions (IS) or seedlings treated with nano silica $\left(\right.$ IS $\left.^{\mathbf{o}}\right)$. 


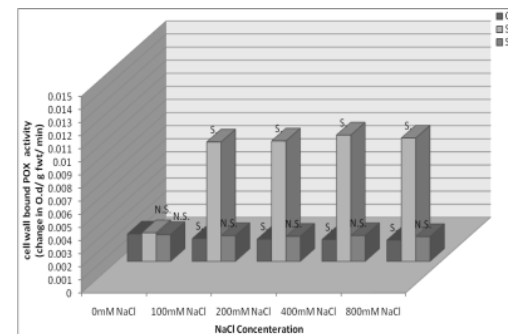

Fig. 64. The change in cell wall bound POX activity in Rice seedlings after 6 days from salt irrigation.

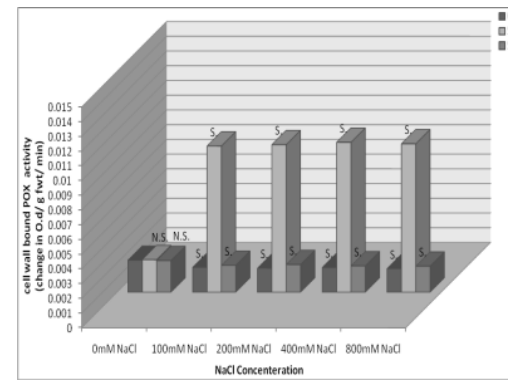

Fig. 66. The change in cell wall bound POX activity in Rice seedlings after 9 days from salt irrigation .

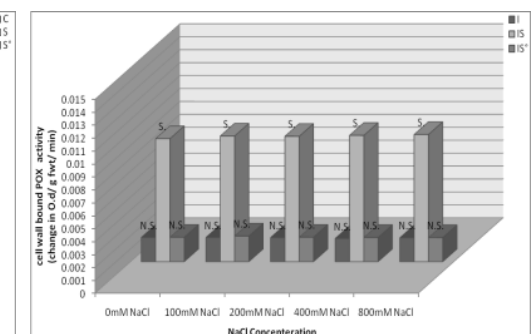

Fig. 65. The change in cell wall bound POX activity in Rice seedling after 6 days from salt irrigation and Fusarium infection.

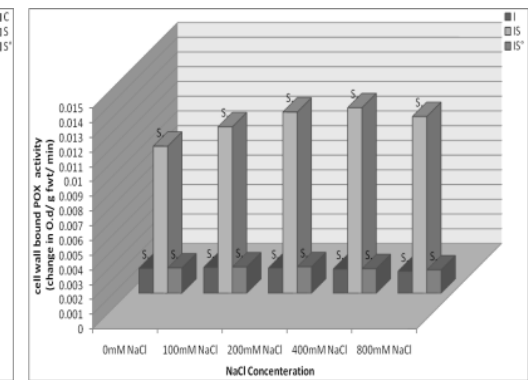

Fig. 67. The change in cell wall bound POX activity in Rice seedling after 9 days from salt irrigation and Fusarium infection .

Proline

The results in Figs. 68-73 show the change in proline content in rice plants as a result of salt irrigation and/ or Fusarium infection either in silica ions application or nanosilica application where: Nanosilica application non significantly decreased the proline content in wheat and rice while the silica ions application non significantly increased its content, while salt irrigation and/or infection caused in significant increase in the proline content of non treated plants, nanosilica treated plants and silica ions application. In case of the silica ions application the increase ratio was the highest. This increase in proline content as aresult of stress in this work can be explained as one of the adaptations of plants to stress. In this respect it was found that proline metabolism is highly responsive to a number of carbohydrates, especially when the internal concentrations exceed a critical level, which might occur because of dehydrateion (Kavi Kishor et al., 2005). Zhang et al. (2013) suggested that changes in DNA methylation (demethylation) as a result of osmotic stress facilitate proline accumulation via the up-regulation of proline metabolism-related gene expression (e.g., P5CS and $\delta$-OAT), which is likely an adaptive response to the stress. A positive correlation between magnitude of free proline accumulation and stress 
tolerance has been suggested as an index for determining stress tolerance potentials among cultivars (Misra and Gupta, 2005).

The results of the present work indicate that nano silica could not improve the biochemical status of rice seedling under stress might be explained as the nanoparticles adhere to plant roots and exert physical or chemical toxicity to plants. It needs to be cautioned that the inhibition of plant growth might not be derived directly from chemical phytotoxicity of nanoparticles. Instead, toxicity may result from the physical interactions between nanoparticles and plant cell transport pathways. This might inhibite apoplastic trafficking by blockage of the intercellular spaces in the cell wall or cell wall pores, or the symplastic connections between cells through blockage of the nano-sized plasmodesmata (Ma et al., 2010). Moreover, toxicity of NPs might involve production of hydroxyl radicals due to visible light generating extracellular reactive oxygen species that would then damage cell membranes and result in change of the membrane permeability and consequently, the probability of entry of NPs into the cell increases and the toxicity increase (Elena and Král'ová, 2013).

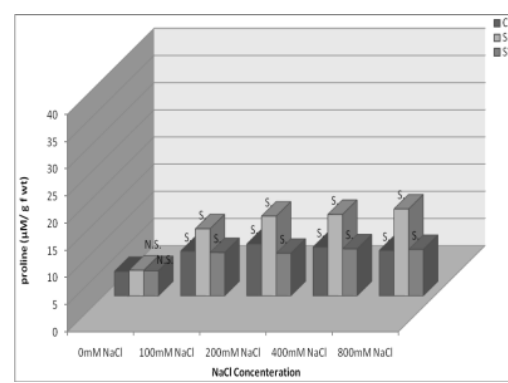

Fig. 68. The change in proline content in Rice seedlings after 3 days from salt irrigation either in non treated seedlings (C) or seedlings treated with silica ions (S) or seedlings treated with nano silica $\left(\mathbf{S}^{\mathbf{o}}\right)$.

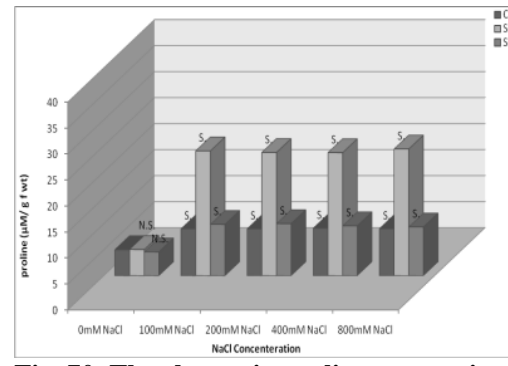

Fig. 70. The change in proline content in Rice seedlings after 6 days from salt irrigation .

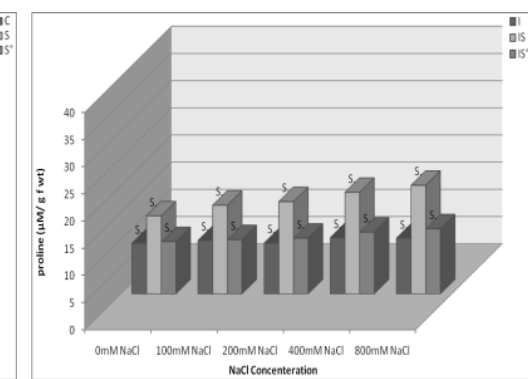

Fig. 69. The change in proline content in Rice seedling after 3 days from salt irrigation and Fusarium infection either in in non treated seedlings (I) or seedlings treated with silica ions (IS) or seedlings treated with nano silica $\left(\mathrm{IS}^{\circ}\right)$.

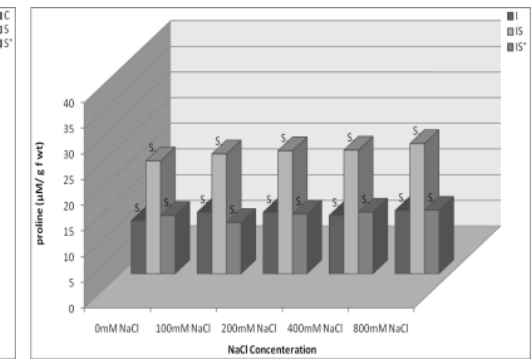

Fig. 71. The change in proline content in Rice seedling after 6 days from salt irrigation and Fusarium infection 


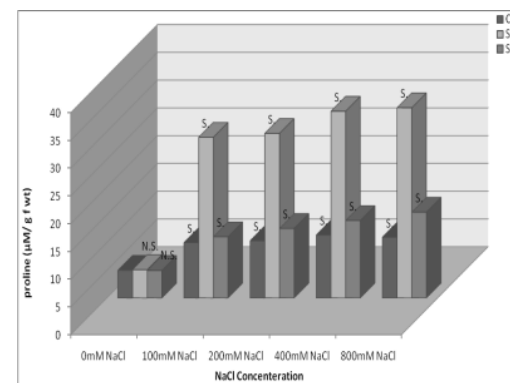

Fig. 72. The change in proline content in Rice seedlings after 9 days from salt irrigation .

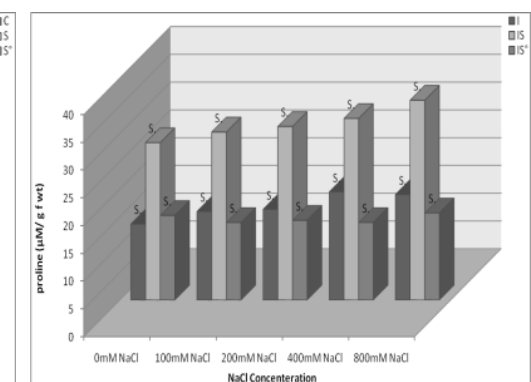

Fig. 73. The change in proline content in Rice seedling after 9 days from salt irrigation and Fusarium infection .

\section{References}

Adam, F. and Fua, H. K. (2008) Production of silica from biogenic material. Malaysian Patent No.: MY-136715-A

Agrawal, G. K., Iwahashi, H. and Rakwal, R. (2003) Small GTPase 'Rop': molecular switch for plant defense responses. FEBS Letters, 546: 173-180

Alexieva, V., Sergio, I., Mapelli, S. and Karanov, E. (2001) The effect of drought and ultraviolet radiation on growth and stress markars in pea and wheat. Plant Cell Environment, 24: 1337-1344.

Ali, H. M., Siddiqui, M. H., Basalah, M.O., Al-Whaibi, M.H., Sakran, A.M. and AlAmri A. (2012) Effects of gibberellic acid on growth and photosynthetic pigments of Hibiscus sabdariffa L. under salt stress. African Journal of Biotechnology, 11: 800804.

Amtmann, A. and Beilby, M. (2010) The role of ion channels in plant salt tolerance. In: "Ion Channels and Plant Stress Responses". Demidchik, V., Maathuis, F. (Ed.), 23-46. Springer-Verlag, Berlin.

Barkla, B. J. and Pantoja, O. (2011) Plasma Membrane and Abiotic Stress. In: "The Plant Plasma Membrane, Plant Cell Monograph". Murphy A.S., Schulz B. Peer W. (Eds.), 457-470. Springer Berlin Heidelberg

Bates, L.S., Waldren, R.P. and Tear, I.D. (1973) Rapid determination of free proline for water-stress studies. Plant and Soil, 39: 205-207.

Beyer, Jr. W. F. and Fridovich, I. (1987) Assaying for superoxide dismutase activity: Some large consequences of minor changes in conditions. Analytical Biochemistry, 161: $559-566$

Bhattachrjee, S. (2005) Reactive oxygen species and oxidative burst: Roles in stress, senescence and signal transduction in plant. Current Science 89, 1113-1121. 
Brunner, T.J., Wick, P., Manser, P., Spohn, P., Grass, R.N., Limbach, L.K., Bruinink, A. and Stark, W.J. (2006) In vitro cytotoxicity of oxide nanoparticles: Comparison to asbestos, silica, and the effect of particle solubility. Environmental Science Technology, 40: 4374-4381.

Datnoff, L.E., Rodrigues, F.A., Benhamou, N., Jones, J.B. and Be'langer, R.R. (2003) Ultrastructural and cytochemical aspects of silicon-mediated rice blast resistance. Phytopathology, 93: 535-546.

Dempsey, D.A. and klessig, D.F. (1995) Signals in plant disease resistance. Bull Institute Pasteur, 93: 167-186.

Dianzani, M. and Barrera, G. (2008) Pathology and physiology of lipid peroxidation and its carbonyl products. In: "Free Radical Pathophysiology", Álvarez, S.; Evelson, P. (Ed.), 19-38 Transworld Research Network: Kerala, India.

Elena, M. and Král'ová, K. (2013) Metal nanoparticles and plants. Ecological Chemistry Engineering Seince, 20: 9-22.

Fam, S.S. and Morrow, J.D. (2003) The isoprostanes: Unique products of arachidonic acid oxidation-a review. Current Medical Chemistry, 10: 1723-1740.

Fujiwara, K., Suematsu, H., Kiyomiya, E., Aoki, M., Sato, M. and Moritoki, N. (2008) Size-dependent toxicity of silica nanoparticles to Chlorella kessleri. Journal of Environmental Science and Health, Part A, 43: 1167-1173.

Gill, S.S. and Tuteja, N., (2010) Reactive oxygen species and antioxidant machinery in abiotic stress tolerance in crop plants. Plant Physiology and Biochemestry, 48: 909-930.

Gomathi, R., Vasantha, S., Shiyamala, S. and Rakkiyappan, P. (2013) Differential accumulation of salt induced proteins in contrasting sugarcane genotypes. European Journal of Biological Sciences, 6:7-11.

Guo, Q., Lin M., Peichun, M. and Xiaoxia, T. (2013) Role of silicon in alleviating saltinduced toxicity in white clover. Bulletin of environmental contamination and toxicology, 91: 213-216

Haghighi, M. and Pessarakli, M. (2013) Influence of silicon and nano-silicon on salinity tolerance of cherrytomatoes (Solanum lycopersicum L.) at early growth stage. Scientia Horticulturae, 161: 111-117.

Jacobs, A., Ford, K., Kretschmer, J., Tester, M. (2011) Rice plants expressing the moss sodium pumping ATPase PpENA1 maintain greater biomass production under salt stress. Plant Biotechnology Journal, 9: 838-847.

Jaleel, C.A., Manivannan P., Kishorekumar A., Sankar B., Gopi R., Somasundaram, R. and Panneerselvam, R. (2007) Alterations in osmoregulation, antioxidant enzymes and indole alkaloid levels in Catharanthus roseus exposed to water deficit. Colloids surface. B: Biointerfaces, 59: 150-157.

Kar, M. and Mishra, D. (1976) Catalase, peroxidase, and polyphenoloxidase activities during rice leaf senescence. Plant Physiology, 57: 315-319.

Egypt. J. Bot., 55, No. 1 (2015) 
Karuppanapandian, T., Jun-Cheol M., Kim C., Kumariah, M. and Wook, K. (2011) Reactive oxygen species in plants: Their generation, signal transduction, and scavenging mechanisms mechanisms, Ajustralian Journal of Crop science, 5(6): 709-725.

Kavi Kishor, P. B., Sangam, S., Amrutha, R. N., Sri Laxmi, P., Naidu, K. R., Rao, K. R. S., Sreenath, Rao, Reddy, K.J., Theriappan, P. and Sreenivasulu, N. (2005) Regulation of proline biosynthesis, degradation, uptake and transport in higher plants: Its implications in plant growth and abiotic stress tolerance. Current Science, 88: 424-438.

Lee, S. K., Sohn, E.Y., Hamayun, M., Yoon, J. Y. and Lee, I. J. (2010) Effect of silicon on growth and salinity stress of soybean plant grown under hydroponic system. Agroforest System, 80: 333-340.

Li, H.S. (2000) Principles and techniques of plant physiological biochemical experiment higher education press, Beijing, 260- 263 (in Chinese)

Liang, Y., Sun, W., Zhu, Y.G. and Christie, P. (2007) Mechanisms of Silicon-mediated alleviation of abiotic stress in higher plants, A Review Environmental Pollution, 147 422-428.

Liang, Y.C., Zhang, W.H., Chen, Q. and Ding, R.X. (2005) Effects of silicon on tonoplast Hp-ATPase and Hp-PPase activity, fatty acid composition and fluidity in roots of salt-stressed barley (Hordeum vulgare L.). Environmental and Experimental Botany, 53: 29-37.

Lin, W., Huang, Y. W., Zhou, X. D. and Ma, Y. (2006) In vitro toxicity of silica nanoparticles in human lung cancer cells. Toxicology and Applied Pharmacology, 217(3): 252-259.

Ma, H., Song, L., Shu, Y., Wang, S., J. Niu, Zhankui Wang, Yu T., Gu W. and Ma, H. (2012) Comparative proteomic analysis of seedling leaves of different salt tolerant soybean genotypes. Journal of Proteomics, 75: 1529-1546.

Ma, J.F., Tamai K., Yamaji, N., Mitani, N., Konishi, S., Katsuhara ,M., Ishiguro, M. Murata, Y. and Yano, M. (2006) A silicon transporter in rice. Nature, 440: 688-691.

Ma, X., Geiser-Lee, J., Deng, Y. and Kolmakov, A. (2010) Interactions between engineered nanoparticles (ENPs) and plants: Phytotoxicity, uptake and accumulation. Science of the Total Environment, 408: 3053-3061.

Mansour, M.M.F. (2013) Plasma membrane permeability as an indicator of salt tolerance in plants. Biologica Plantrum, 57 (1): 1-10.

Mansour, M.M.F. (1997) Cell permeability under salt stress. In: "Strategies for Improving Salt Tolerance in Higher Plants", Jaiwal, P.K., Singh, R.P., Gulati, A. (Ed.), 87-110. Science Publication, Enfield.

Metzner, H., Raum, H. and Senger, H. (1965) Unterschungen Zur Sychno-nisier-Barkeit einze-Iner Pigmenmangel-Mutanten-von. Chlorella. Planta, 65: 186. 
Miller, G., Suzuki, N., Ciftci-Yilmaz, S., Mittler, R. (2010) Reactive oxygen species homeostasis and signalling during drought and salinity stresses. Plant Cell and Environment, 33: 453-467.

Misra, N. and Gupta, A. K. (2005) Effect of salt stress on proline metabolism in two high yielding genotypes of green gram. Plant Science, 169: 331-339.

Mittler, R., Vanderauwera, S., Gollery, M. and Van Breusegem, F. (2004) Reactive oxygen gene network of plant. Trends Plant Science, 9(10): 490-498.

Navrot, N., Roubier N., Gelbaye E. and Jacquot, J.P. (2007) Reactive oxygen species generation and antioxidant systems in plant mitochondria. Physiology Plantrum, 129: 185-195.

Petrov, and Van Breusegem (2012) Hydrogen peroxide is a hub for information flow in plants, Aob Pants, 16: 1-13.

Poovaiah, B.W. and Leopold, A.C. (1973) Deferral of leaf. senescence with calcium. Plant Physiology, 52: 236-239.

Russell, N.J. (1989) Functions of lipids: Structural roles and membrane functions. In: "Microbial Lipids", Ratledge, C., Wilkinson, S.C. (Ed.)., Academic Press, London. 279-365.

Saroop, S., Chanda, S.V. and Singh, Y.D. (2002) Changes in Soluble and Ionically Bound Peroxidase Activities during Brassica juncea seed development. Bulgarian Journal of Plant Physiology, 28: 26-34.

Savant, N.K., Datnoff, L.E. and Snyder, G.H. (1997) Depletion of plant available silicon in soils: A possible cause of declining rice yields. Communications in Soil Science and Plant Analysis, 28: 1245-1252.

Sharma, P., Ambuj, B.J., Dubey, R.S. and Mohammad, P. (2012) Reactive oxygen species, oxidative damage, and antioxidative defense mechanism in plants under stressful conditions. Journal of Botany, 1-26.

Szabados, L. and Savouré, A., (2010) Proline: A multifunctional amino acid. Trends in plant science, 15: 89-97.

Terzi, R., Saruhan, G.N., Kutlu-Çaliskan, N. and Kadioglu, A. (2013) Lignification response for rolled leaves of Ctenanthe setosa under long-term drought stress. Turkish Journal of Biology, 37: 1-7.

Wang, C.Q. and Song, H. (2009) Calcium protects Trifolium repens L. seedlings against cadmium stress. Plant Cell Reproduction, 28:1341-1349.

Wassall, S.R. and Stillwell, W. (2009) Polyunsaturated fatty acid cholesterol interactions: domain formation in membranes. Biochimica et Biophysica Acta, 1788: 24-32.

Upadhyaya, A., Sankhla, D., Davis, T.D., Sankhla, N. and Smith B.N, (1985) Effect of paclobutrazol on the activities of someenzymes of activated oxygen metabolismand lipid per oxidation in senescing soybean leaves, Journal of Plant Physiology, 121: 453-461.

Egypt. J. Bot., 55, No. 1 (2015) 
Zamani, S., Bybordi, A., Khorshidi, S. and Nezami, T. (2010) Effects of $\mathrm{NaCl}$ salinity levels on lipids and proteins of canola (Brassica napus L.) cultivars. Advances in Environmental Biology, 4: 397- 403.

Zhang, C.Y., Wang, N.N., Zhang, Y.H., Feng, Q.Z., Yang, C.W. and Liu, B. (2013) DNA methylation involved in proline accumulation in response to osmotic stress in rice (Oryza sativa). Genetics and Molecular Research, 12 (2): 1269-1277.

Zhu, Z.J., Wei, G.Q., Li, J., Qian, Q.Q. and Yu, J.Q. (2004) Silicon alleviates salt stress and increases antioxidant enzymes activity in leaves of salt-stressed cucumber (Cucumis sativus L.). Plant Science, 167: 527-533.

(Received 16/9/2014; accepted 8/1/2015)

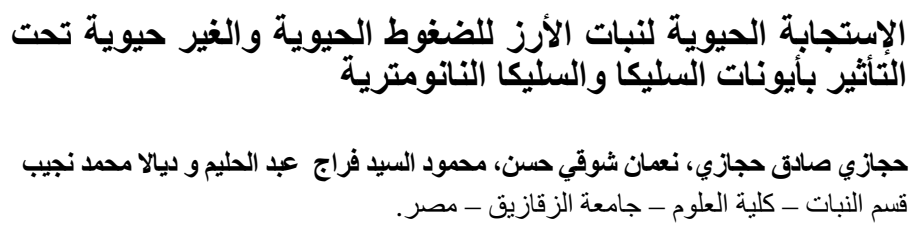

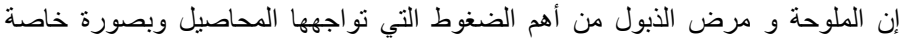

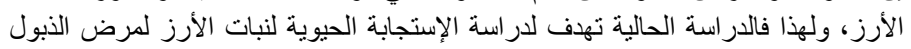

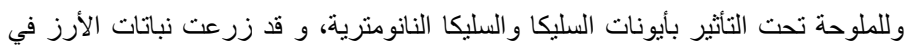

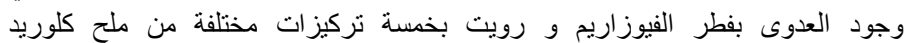

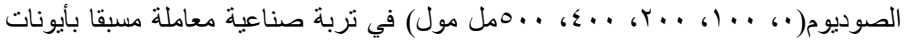

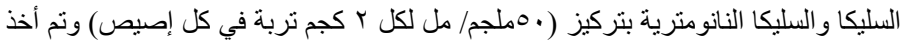

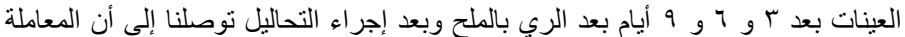

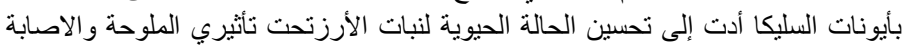

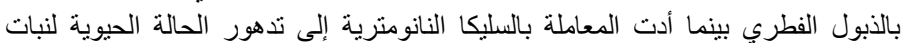
الأرزتحت ذات الظروف الملوحة والاصنابة بالذبول الفطري. 